\title{
Effect of Low and High Doses of Vitamin D on Streptozotocin- Induced Diabetic Nephropathy in Adult Male Albino Rats: Histological and Immunohistochemical Study
}

\author{
Rania Ebrahim, Ola Mostafa and Enas Mohamed
}

Histology and Cell Biology Department, Faculty of Medicine, Benha University

\begin{abstract}
Background: Diabetic nephropathy is an important instigate of persistent kidney ailment problem and irrevocably renal catastrophe. Vitamin D (VD) insufficiency is documented as a worldwide health delinquent and lately pondered as a conscientious factor in the onset and progression of diabetes mellitus (DM).

Aim: This research paper was premeditated to explore the probable upshot of low and high doses of vitamin D on a rat model of diabetic nephropathy.

Material and Methods: Forty adult male albino rats were segregated into four groups: Group I (control group). Group II (the diabetic nephropathy group): given streptozotocin intraperitoneal. Group III (the low dose VD group): rats were given streptozotocin then vitamin D orally as $8000 \mathrm{IU} / \mathrm{kg} /$ day. Group IV (the high dose VD group): rats were given streptozotocin then vitamin D orally as $20,000 \mathrm{IU} / \mathrm{kg} /$ day. After complete 12 weeks from the beginning of the experiment, rats were sacrificed. Kidney specimens were handled and assayed by histological and Immunohistochemical procedures.

Results: The diabetic nephr0pathy group revealed distortion of glomeruli, tubular distortion. mononuclear permeation and epithelial desquamation. Congested dilated glomeruli, peritubular blood vessels and interstitial outpouring of blood were also noticed. EM examination of proximal and distal c0nv0luted tubules exhibited multiple vacuoles. thickening of basement membrane and destructed mitochondria were also seen. Group III showed improvement of these changes and Group IV showed amelioration of most of these changes.

Conclusion: High dose of vitamin D ameliorates experimentally induced diabetic nephropathy.
\end{abstract}

Received: 25 February 2019, Accepted: 27 February 2019

Key Words: Antifibronectin, basement membrane, electron microscope, renal cortex, vitamin D.

Corresponding Author: Rania Ebrahim Eldesoky, PhD, Histology and Cell Biology Department, Faculty of Medicine, Benha University, Cairo, Egypt, Tel.: +20 1004373768, E-mail: doc.rania@yahoo.com

ISSN: 1110-0559, Vol. 42, No. 3

\section{INTRODUCTION}

Diabetic nephropathy $(\mathrm{DN})$ is a definite sticky wicket of diabetes mellitus and inevitably clues to renal failure ${ }^{[1]}$. Inflammatory cytokines and pro-inflammatory factors are the most morbific reason for DN. consequently, DN has been thought-about as Associate in Nursing disease $^{[2]}$. moreover, the involvement of 0xidative stress as a main player within the path010gic process, onset, and progression of DN; was established within the recent experimental researches DN has been considered as an inflammatory disease $\mathrm{e}^{[3]}$. Oxidative stress triggers multiple pathogenic alleyways as, renin- angiotensin-aldosterone system (RAAS). advanced glycation end-product (AGEs) and protein kinase C-B (PKC-B) were another alleyway directs to advanced renal injures ${ }^{[4]}$.

Lately vitamin D is considered as a pro-hormone. It is important for keeps altogether mammals. it's gift in foods and is made via a reaction within the $\operatorname{skin}^{[5]}$. Vitamin D is of public health renowned because; its deficiency is common. D shortage is related to contractor disorders, vessel disorders and skin infections ${ }^{[6]}$.
Vitamin D metabolism proceeds by the liver then the kidney and other tissues. Recently, both paracrine and endocrine actions of vitamin $\mathrm{D}$ have been broadly acknowledged. It is pondered as a pleiotropic hormone with plentiful regulatory possessions. It triggers control calciumphosphorus metabolism and bone mineralization ${ }^{[7]}$.

Vitamin D3 has multiple important tasks contiguous with the organizing mineral metabolism. The immune system adaptation $^{[8]}$ and cardiovascular system modulation ${ }^{[9]}$ are examples of VD functions. The dwindling levels of VD are linked to extreme blood pressure ${ }^{[10]}$. Vitamin D has a crucial role in developmental metabolic imbalances, for instance; obesity and diabetes ${ }^{[11]}$. Vitamin D is additionally connected with progression of nephrosis. The mechanism of urinary organ malfunction is interrupting varied cell differentiation and proliferation ${ }^{[12]}$. Recent researches have demonstrated that low plasma level of VD insufficiency is a prominent cause of various types of cancer, including prostate $^{[13]}$ colorectal $^{[14]}$, and breast cancer ${ }^{[15]}$. Vitamin D has a potential anticancerous validity, as it encourages cancer cells differentiation and apoptosis and preclude their migration ${ }^{[16]}$. 


\section{AIM OF THIS STUDY}

To inspect the probable consequence of low and high dose of vitamin D on streptozotocin- induced diabetic nephropathy in rats.

\section{MATERIALS AND METHODS}

\section{Drugs, compounds and reagent kits}

Streptozotocin (STZ) and Vitamin D were purchased from Sigmaa-Alderich (St. Louis, MO). The biological, chemical parameters and kits were acquired from Swemeed Biomedicals Pvt. Ltd. (Bengalauru, India). Wholly the chemicals employed in the study were purchased from accepted commercial suppliers.

\section{Animals}

forty healthy male albino rats (ranging 160-180 gm) were gotten from the animal house, Mochtouhor faculty of Veterinary Medicine, Benha University. Rats were separated into four cages. Every cage contains 10 rats, with regulated surroundings (12-h dark/light cycle, $26 \pm 3{ }^{\circ} \mathrm{C}$ temperature and $55 \pm 10 \%$ humidity). Rats were fed with customary diet and had free accession to water impromptu (El-gomhoreyaa Company, Cairo, Egypt). Experimental ethics and procedure agreed with the global ethical guidelines for animal caution. Confirmation was done by the ethical committee, Faculty of medicine, Benha University, Egypt.

\section{Provocation of Experimental Diabetes}

Diabetes was invoked in rats that were fasted for twelve hours, then injected with streptozotocin (40 mg/kg) intraperitoneally (the injection volume was 1 $\mathrm{ml} / \mathrm{rat}$ ). Injection was for 5 sequential days. The injected streptozotocin was dissolved in freshly prepared citrate buffer (0.1 M, pH 4.5). Confirmation of diabetes was established after $72 \mathrm{~h}$ via evaluating the fasting blood glucose (FBG) concentration. The animals with FBG level surpassing $235 \mathrm{mg} / \mathrm{dl}$ were thought-about diabetic and were used for the accomplishment of the tria[ ${ }^{[17]}$.

\section{Experimental strategy}

The animals were dispersed into four sets as the following:

Group I (control, $\mathrm{n}=10$ ): rats were dispersed into three subgroups:

1. Subgroup Ia $(n=4)$ : rats received an intraperitoneal injection of $1 \mathrm{ml}$ of citrate buffer (pH4.2) for 5 sequential days.

2. Subgroup $\mathrm{Ib}(\mathrm{n}=3)$ : rats received VD orally as $8000 \mathrm{IU} / \mathrm{kg}$ every day till the end of the $12^{\text {th }}$ week (the duration of the experiment).

3. Subgroup Ic $(n=3)$ : rats received VD orally as $20,000 \mathrm{IU} / \mathrm{kg}$ every day till the end of the $12^{\text {th }}$ week (the duration of the experiment).
Group II (the diabetic group, $\mathrm{n}=10$ ): rats received an intraperitoneal inoculation of $40 \mathrm{mg} / \mathrm{kg}$, STZ freshly liquified in citrate buffer ( $\mathrm{pH} 4.2$ ) for 5 sequential days.

Group III (the low dose VD group, $\mathrm{n}=10$ ): rats received intraperitoneal inoculation of $40 \mathrm{mg} / \mathrm{kg}, \mathrm{STZ}$ freshly liquified in citrate buffer ( $\mathrm{pH} 4.2)$ for 5 sequential days. Then they were given VD orally as $8000 \mathrm{IU} / \mathrm{kg}$ every day till the end of the 12th week from the commencement of the experiment ${ }^{[18]}$.

Group IV (the high dose VD group, $\mathrm{n}=10$ ): rats received an intraperitoneal inoculation of $40 \mathrm{mg} / \mathrm{kg}$, STZ freshly liquified in citrate buffer ( $\mathrm{pH} 4.2)$ for 5 sequential days, then they were given VD orally as $20,000 \mathrm{IU} / \mathrm{kg}$ every day till the end of the $12^{\text {th }}$ week from the commencement of the probationary ${ }^{[18]}$.

The rats were anesthetized with ether and sacrificed by cervical beheading after 12 weeks. right kidneys were fastidiously compound out. Each kidney was alienated into two parts; one was processed for light microscopic checkups plus one for electron microscopic checkups. The animals were eradicated by burning in Benha University Hospital furnace.

The kidney specimens were mounted in $10 \%$ buffered formall saline. They were handled to organize paraffin sections of 5-7 $\mu \mathrm{m}$ thickness, mounted on glass slides for $H$ \& E stain ${ }^{[19]}$. different sections were mounted on +ve charged slides for immunohistochemical inspection ${ }^{[20]}$ using avidin-biotin immunohistochemical staining for detection of antifibronectin. The reaction of fibronectin seems as brown coloration of the extracellular matrix and basement membrane. Positive control sections were of skin sections. Negative control sections were achieved by eliminating the primary antibody.

Blood tasters were attained from the tail vein for measurements of fasting blood sugar level, serum levels of urea and creatinine. The measurements that were quantified via an autoanalyzer (Hitachi nine hundered twelve AutoAnalyzer; Hitachi, Germany) $)^{[21]}$

\section{Electron microscopic studies}

Specimens from the kidney were fixed in $3 \%$ glutaraldehyde then post-fixed in $1 \%$ osmium tetraoxide. Semithin sections $(0.5-1 \mu \mathrm{m}$ thick) were processed and stained thru toluidine blue. Ultrathin sections (seventy to ninety $\mathrm{nm}$ thick) were expurgated from target areas in semithin sections, mounted on cupper grids and counterstained by uranyl acetate with lead citrate. Specimens were processed ${ }^{[22]}$ and assessed exploiting the transmission electron microscope JEOL (JEM-100 SX Akishima, Tokyo, Japan) in Electron Microscope Unit, Faculty of Medicine, Tanta University.

\section{Statistical analysis}

Wholly parameters for altogether groups (fasting blood glucose, serum levels of urea and creatinine 
and area $\%$ of antifibrenoctin immunecorollary) were articulated as mean \pm SD. The statistics were succumbed to SPSS software package (SPSS Inc., Chicago, Illinois, USA). Statistically significant divergence was determined by one- manner analysis of discrepancy, afterwards the least significant discrepancy assessment for comparisons amid groups. The outcomes were reflected statistically significant, exceedingly significant, and nonsignificant at what time $P$-values were less than 0.05 , less than 0.001 , and greater than 0.05 , respectively.

\section{Morphometric scrutiny}

The mean area ratio of antifibronectin immunoexpression, was computed in ten images from ten nonoverlapping pitches of five slide from each group. The Image-Pro Plus software package version 6.0 (Media Cybernetics Inc., Bethesda, Maryland, USA) was the focal program used in this experiment. The digital photos were captured by Leica DM2500 optical microscopes; in the Microscopic Photography Unit (Histology Department, Faculty of Medicine, Benha University).

\section{RESULTS}

\section{All control sub groups presented the same results}

\section{Serum glucose and renal perform markers}

STZ rats exhibited promotion in blood glucose level as competed to non-diabetic ones. Dispensation of low dose of VD displayed enhancement in serum glucose level as competed to the untreated ones, whilst administration of high dose of VD regressed serum glucose to near normoglycemic measurements (Table 1 and Histogram 1). Serum urea and creatinine levels were ominously raised up in STZ rats by competed with non-diabetic ones, whilst low dose VD treatment abridged these levels as competed to the untreated ones. The high dose VD reverted serum urea and creatinine to near normal levels (Table 2 and Histogram 2,3).

\section{Histological Findings}

\section{Hematoxylin and Eosin Stain}

The renal cortex is personified in the control group by the presence of multiple renal corpuscles and renal tubules (proximal and distal convoluted tubules). Glomeruli were molded of lobulated tufts of capillaries. They were noticed surrounded by Bowman's capsule. The parietal coating of Bowman's capsule was lined by a single coat of simple squamous epithelium (Figure 1).

In the existing analysis, histological checkup of the kidney of diabetic rats concealed apparent enlargement of renal glomeruli with widening of Bowman's spaces. Some renal tubules had darkly stained nuclei, associated with tubular distortion and epithelial desquamation. Congested dilated glomeruli in conjunction with peritubular blood vessels and interstitial hemorrhage were what's more noticed (Figure 2). However, dispensation of low dose VD enhanced improvement of glomerular structure. The proximal and distal convoluted tubules were most probably normal. Some tubular cells were vacuolated (Figure 3). Correspondingly, the administration of high dose VD renal corpuscles and renal tubules were nearly similar to that observed in control rats (Figure 4).

\section{ImmunOhistochemical staining of antifibronectin}

In the contemporary investigation, immunohistochemical analysis of antifibronectin showed faint positive reaction in tubular cells cytoplasm as well as the parietal cells of Bowman's capsule and interstitium (Figure 5). Strong positive reaction was also consulted in diabetic rats in contrast with rats of control group (Figure 6) whilst weak positive reaction was noticed after VD administration surpass with high dose group (Figures 7,8).

\section{Morphometric Results}

The mean area $\%$ of antifibronectin expression for all groups is donated in table 3 and in histogram 4 . Significant increase in expression of antifibronectin was noticed in diabetic rats as contrasted with control rats. There was significant decrease ( $p$ 0.05) in antifibronectin expression in groups III and IV contrasted with group II.

\section{Electron Microscopy Findings}

Electron microscopic examination of the specimens of the control group reveled that, cells coating the proximal convoluted tubule showed numerous apical microvilli, multiple elongated basal mitochondria, and rounded to oval euchromatic nuclei (Figure 9). The DCTs showed curtailed cuboidal cells with euchromatic nuclei, apical few short microvilli. Consistent basal infoldings, and elongated mitochondria amidst was observed (Figure 10). The renal filtration slits between secondary processes of podocytes, glomerular basement membrane with regular thickness. Clear foot processes were observed on the facade of renal basement membrane (Figure 11).

Whereas PCT of the STZ treated rats showed cytoplasmic vacuolation, loss of microvilli with distorted mitochondria. Thick basement membrane, disruption of tubular basal infoldings were distinguished. Irregular nuclei with abnormal chromatin distribution were observed. (Figures 12,13). The DCT showed lateral membrane separation of the cells with cytoplasmic vacuolations and deportation of the cytoplasm into the tubular lumen. Elongated mitochondria and moderately thick basement membrane were also seen (Figure 14). Glomerular basement membrane was thickened with annihilation and distrainment of podocyte foot processes were correspondingly presented (Figure 15).

The renal cortex of low dose VD treated rats showed amendment in the fluctuations in PCT, DCT, podocyte and glomerular basement membrane (Figure 16-18).

The high dose VD group showed conserved renal cortex ultrastructure, PCT and DCT with virtually like that detected in control group ultrastructure. Regular microvilli, 
improvement in the shape of podocytes foot processes were observed. The glomerular basement membrane become more constant in diameter (Figure 19-21).

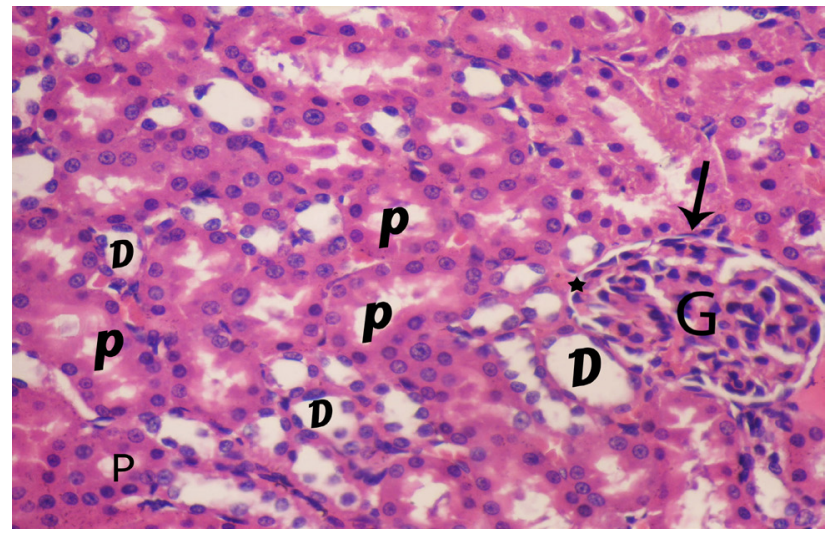

Fig. 1: A photomicrograph of a section in the kidney of a rat from group I (control group), showing renal glomeruli $(\mathrm{G})$ bounded by parietal (arrow) layer of Bowman's capsule. notice Bowman's space (star). proximal (P) and distal convoluted tubules (D). (H\&E x400).

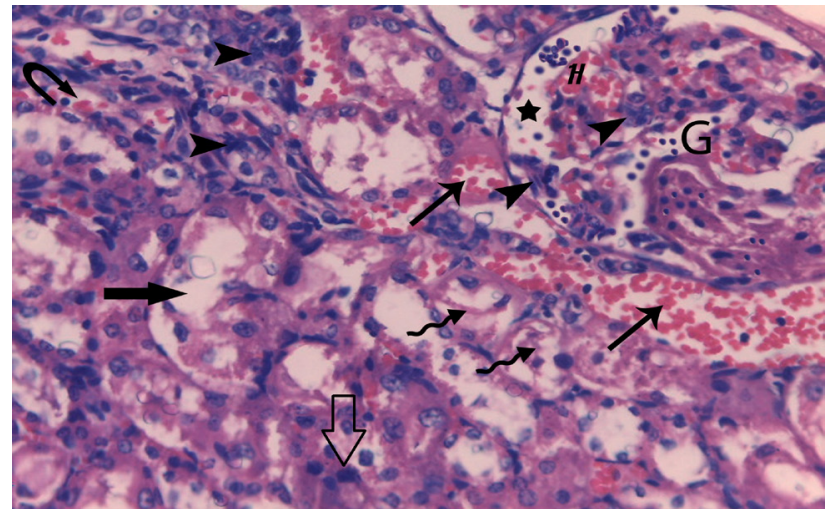

Fig. 2: A photomicrograph of a section in the kidney of a rat from group II (diabetic group), showing apparent broadening of renal glomeruli (G) with widening of Bowman's spaces (black star). Some tubules have darkly stained nuclei (hollow arrow) and tubular distortion is seen (thick arrow). Congested dilated peritubular blood vessels (narrow arrow). interstitial hemorrhage (curved arrow) are likewise seen. Notice desquamated cells (zigzag arrow), congested glomerular capillaries $(\mathrm{H})$ and mono nuclear cellular infiltration (head arrow). (H\&E x400).

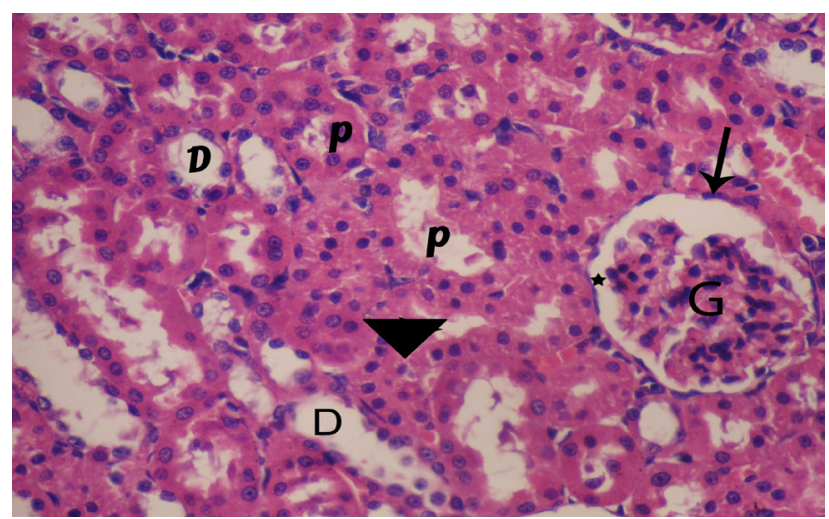

Fig. 3: A photomicrograph of a section in the kidney of a rat from group III (low doseVD group) showing glomerulus (G) with slight glomerular space (star) parietal coating of Bowman capsule (arrow), thereabouts normal proximal (P) and distal convoluted tubules(D). some tubular cells appear vacuolated (head arrow). (H\&E x400).

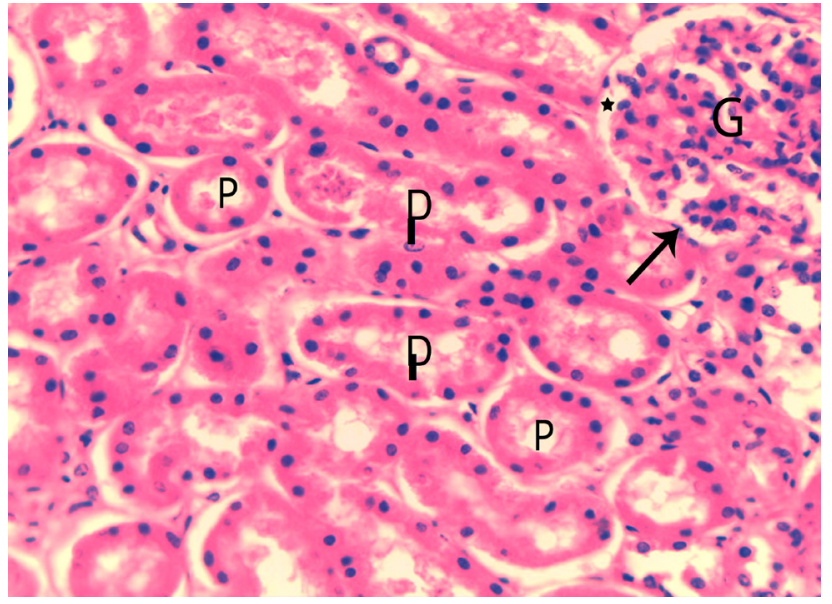

Fig. 4: A photomicrograph of a section in the kidney of a rat from group IV (high doseVD group) showing proximate conventional renal glomeruli $(\mathrm{G})$ thru glomerular space (star). Parietal layer of bowman capsule(arrow) are additionally seen. notice near normal proximal (P) and distal convoluted tubules (D). $\quad(H \& E \times 400)$.

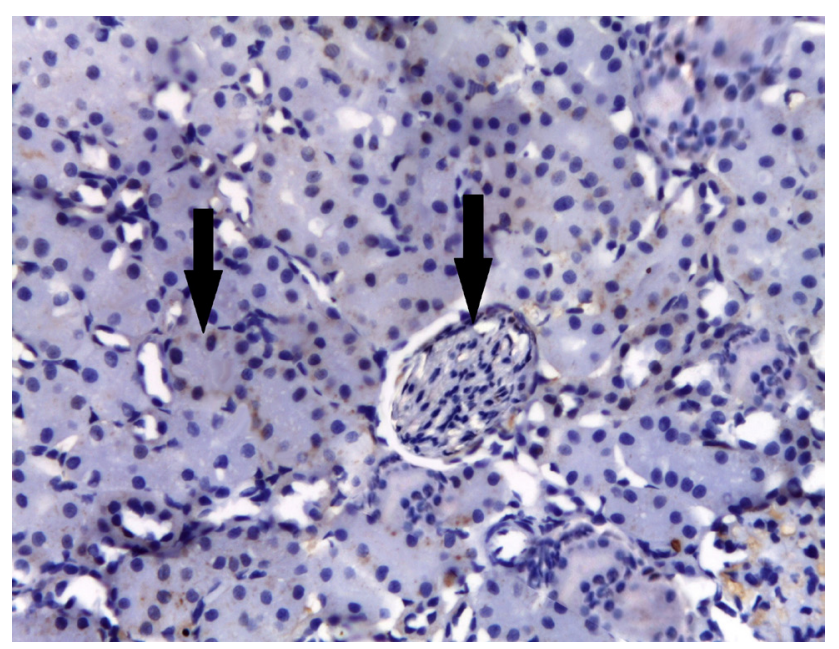

Fig. 5: A photomicrograph of a section in the kidney of a rat from group I (control group), showing very trifling expression of antifibronectin in the glomerulus, tubules along with interstetium (arrow). (antifibronectin immunostaining $\mathrm{x}$ 400)

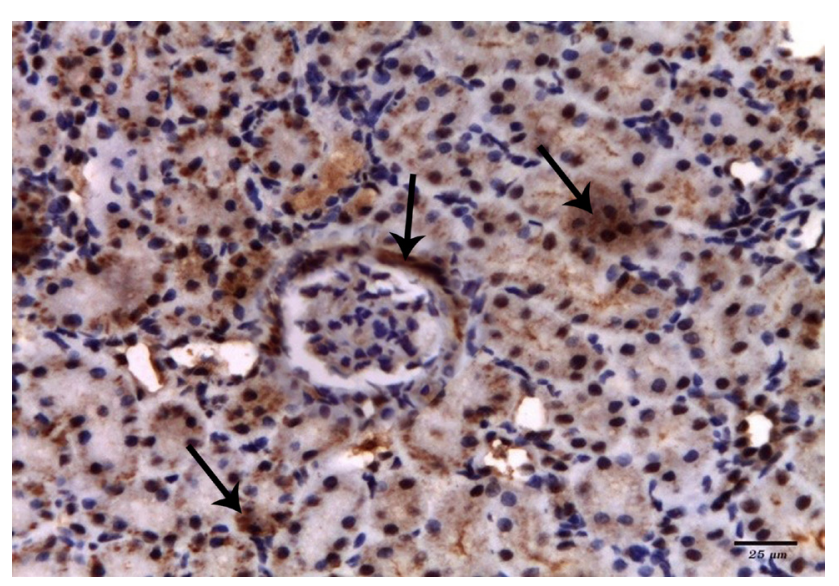

Fig. 6: A photomicrograph of a section in the kidney of a rat from group II (diabetic group) showing strong positive expression of antifibronectin in the glomerulus, renal tubules along with interstetium (arrow). (antifibronectin, immunostaining x 400)) 


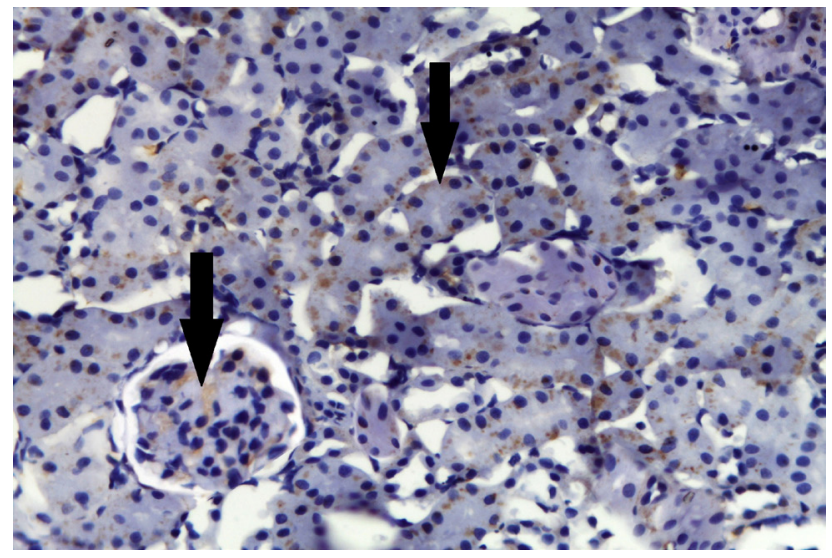

Fig. 7: A photomicrograph of a section in the kidney of a rat from group III (low doseVD group) showing weak positive expression of antifibronectin in the glomerulus, renal tubules as well as interstetium (arrow). (antifibronectin, immunostaining x 400)

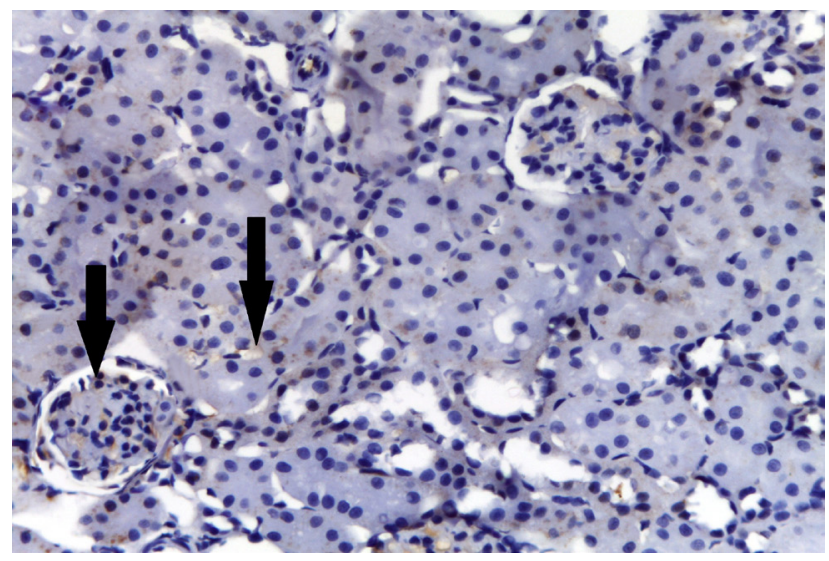

Fig. 8: A photomicrograph of a section in the kidney of a rat from group IV (high doseVD group) showing weak expression of antifibronectin in the glomerulus, renal tubules and interstetium (arrow). (antifibronectin, immunostaining x 400)

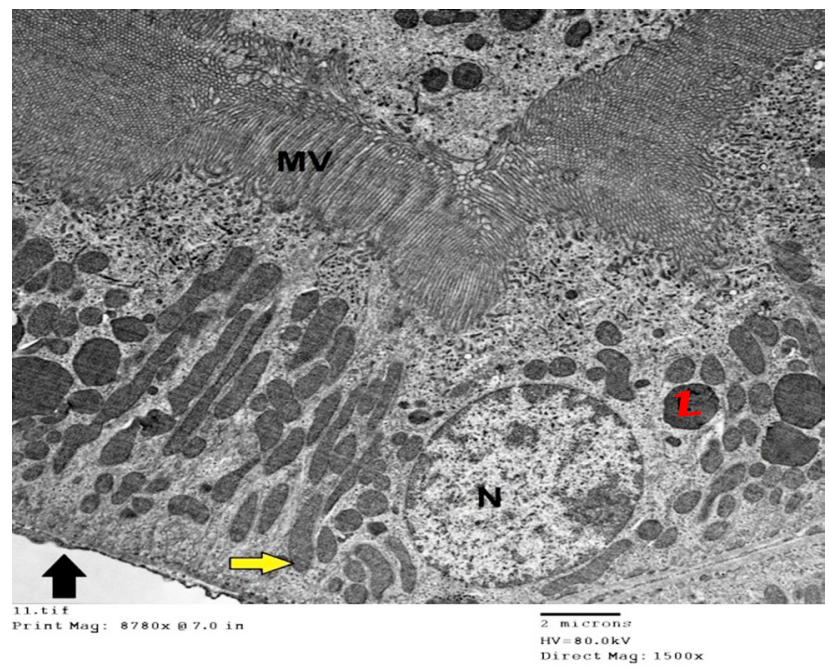

Fig. 9: Transmission electron micrograph of ultrathin sections of cortex of group I (control group), showing element of PCT; central oval euchromatic nucleus $(\mathrm{N})$, basal elongated vertically oriented mitochondria (yellow arrow). Luminal border with long slim packed in microvilli (MV). Slim regular basement membrane (black arrow) and lysosomes(L) can be noticed. (electron microscopy, x8000)

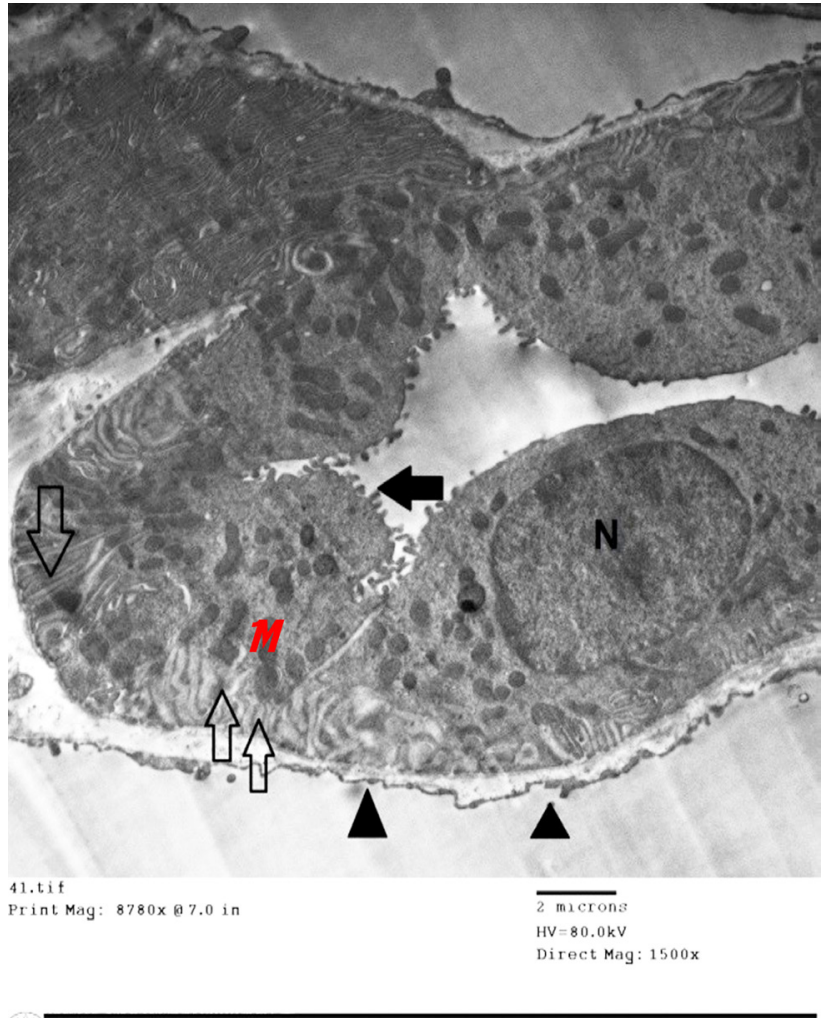

Fig. 10: Transmission electron micrograph of DCT of group I (control group). The cells lining the distal tubules show apical scarce short microvilli (solid arrow). Notice basal infoldings (hollow arrow) and their correlated elongated mitochondria (M) Thin basement membrane (arrow head) and nucleus(N) are also seen. (electron microscopy, x8000)

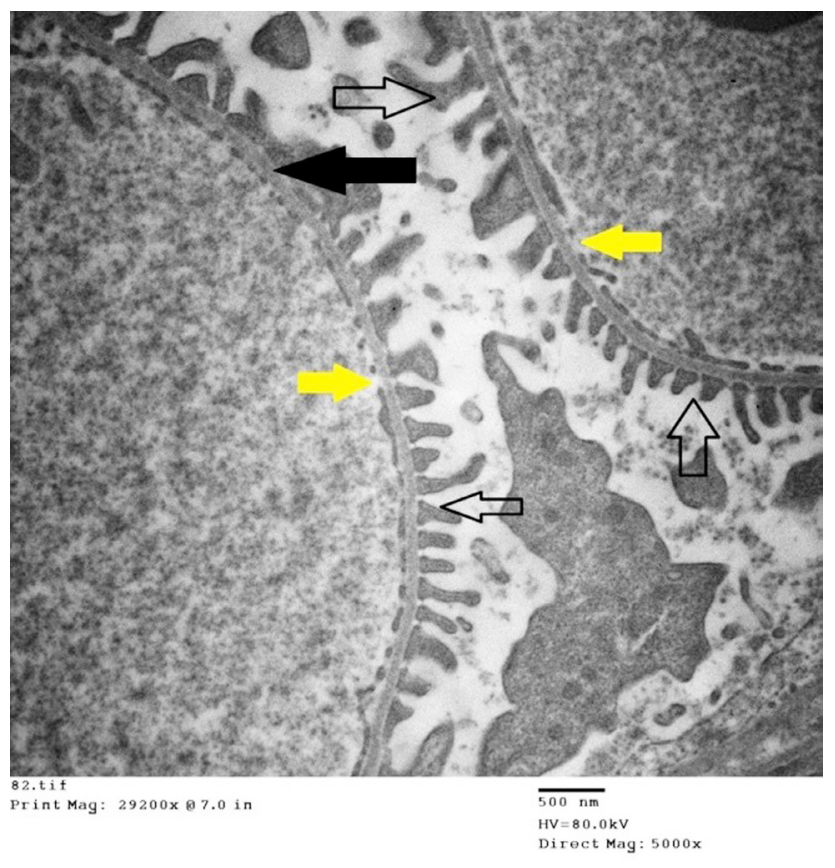

Fig. 11: Transmission electron micrograph of group I (control group), showing glomerular basement membrane (black arrow) which is smooth and of regular diameter. Regularly space out podocyte foot processes (hollow arrow) enclosing in between filtration slits bolted by diaphragm are also observed. Notice endothelial cell fenestrae (yellow arrow). (electron microscopy, x 29200 ) 


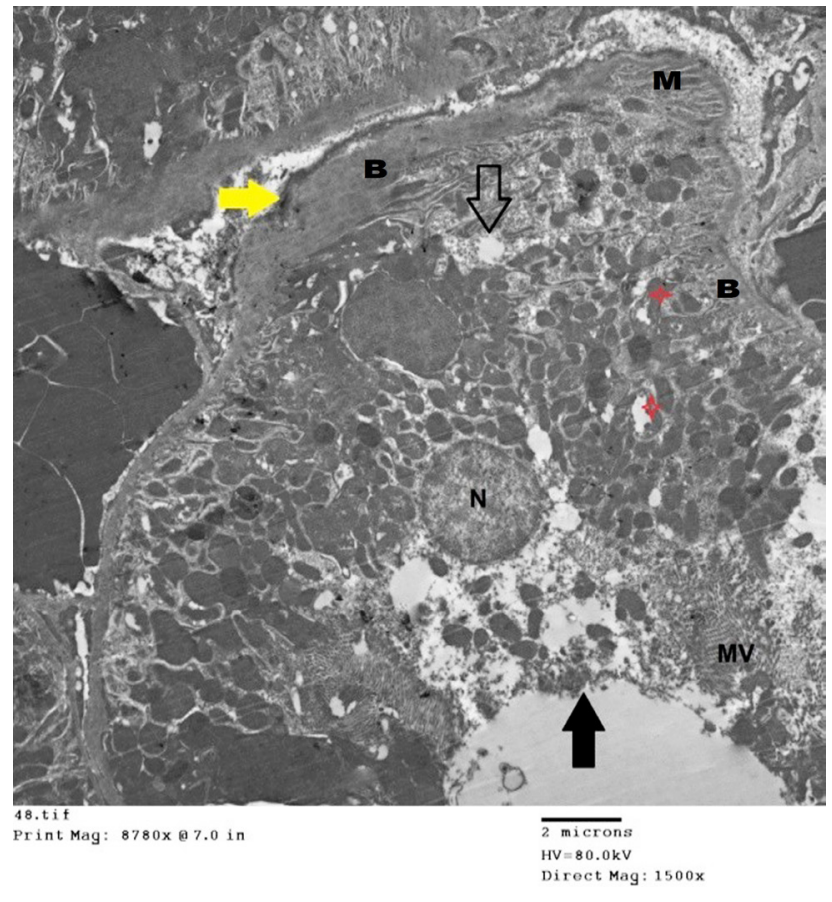

Fig. 12: Transmission electron micrograph of ultrathin sections of renal cortex of group II (diabetic group), showing PCT with congealed basement membrane (yellow arrow). Disruption of tubular basal infoldings (B). and their related mitochondria $(\mathrm{M})$, cytoplasmic vacuoles (hollow arrow). notice, Degenerated mitochondria (star), rarified cytoplasm, rounded small nucleus (N). Denuded luminal border (black arrow) with loss of microvilli (MV) on generally of it. (electron microscopy, x8000)

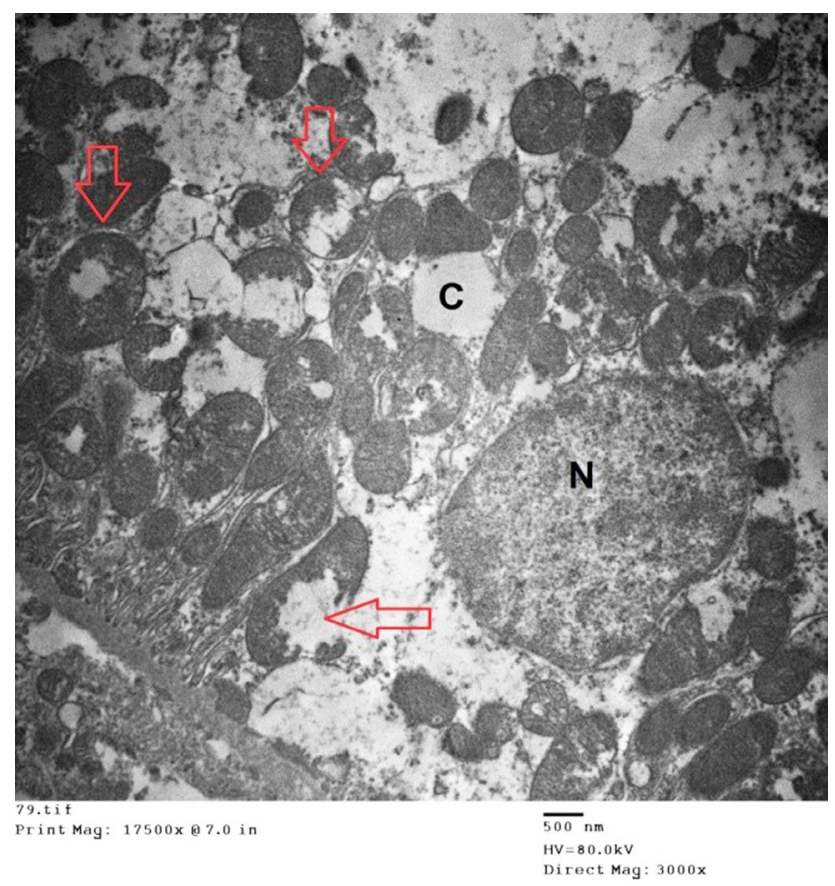

Fig. 13: Transmission electron micrograph of ultrathin sections of group II (diabetic group) renal cortex, showing PCT with vacuolated destructed mitochondria (hollow arrow). Cytoplasmic vacuolations (C), rarified cytoplasm are also observed. notice; Irregular nucleus $(\mathrm{N})$ with abnormal chromatin distribution. (electron microscopy, x17500)

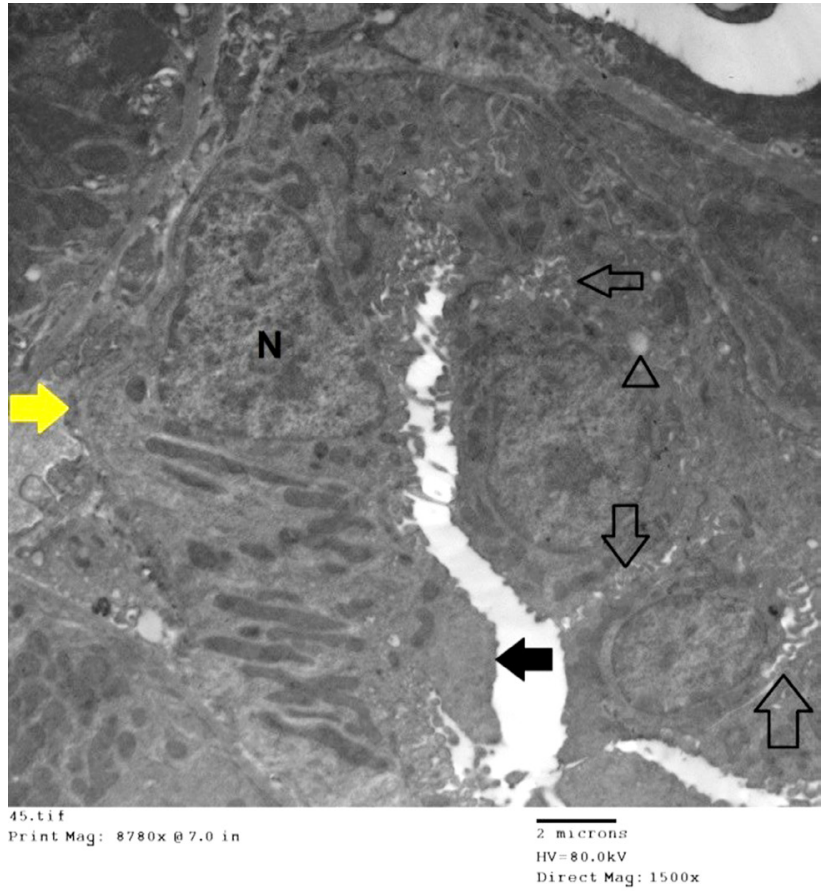

Fig. 14: Transmission electron micrograph of DCT from group II (diabetic group), showing separated lateral membrane (hollow arrow), cytoplasmic vacuole (arrow head). Extruded cytoplasm into the tubular lumen (black arrow), elongated mitochondria and moderately thick basement membrane (yellow arrow) are seen. Notice irregular nucleus(N). (electron microscopy, x 8000)

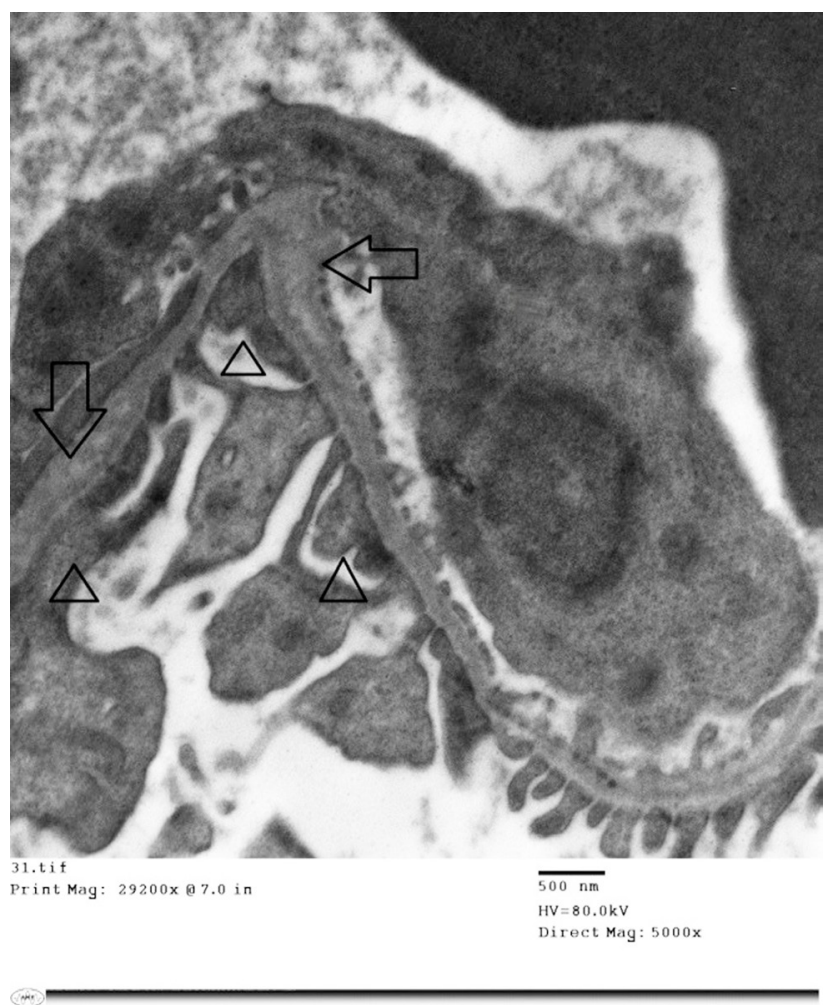

Fig. 15: Transmission electron micrograph of renal cortex from group II (diabetic group), showing glomerular basement membrane which is solidified (arrow) with effacement and disarrangement of podocyte foot processes (arrow head). (electron microscopy, x 29200) 


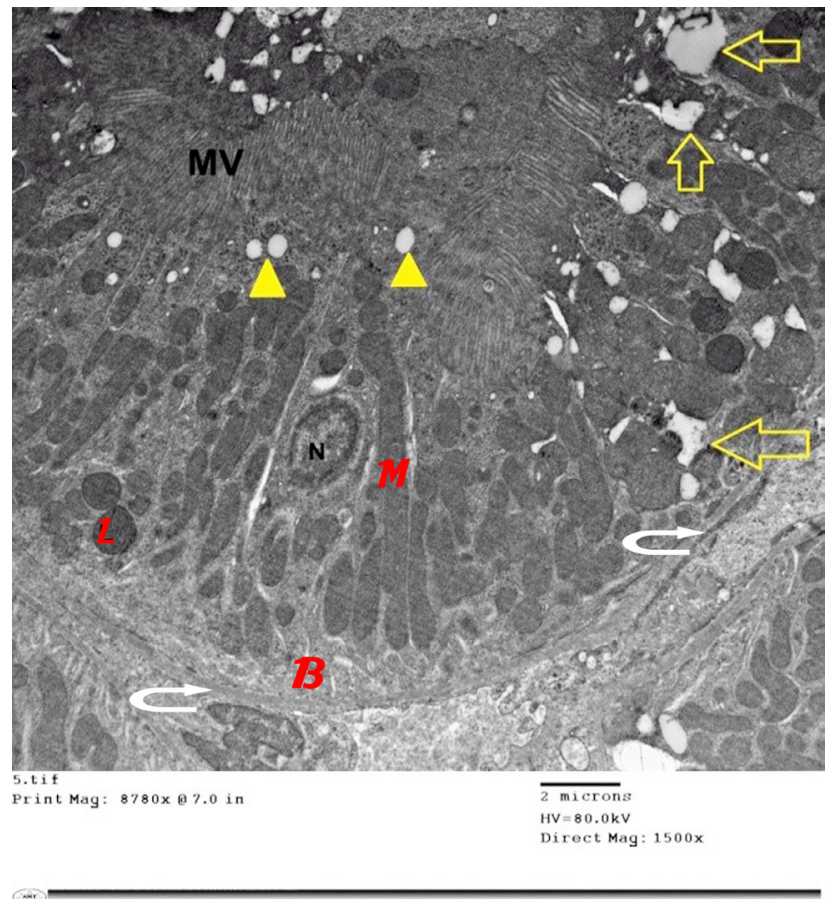

Fig. 16: Transmission electron micrograph of ultrathin sections of cortex of group III (low dose VD group), showing part of PCT with cytoplasmic vacuolations (hollow arrow), endocytotic vesicles (arrow head). Basal elongated mitochondria (M), basal infoldings (B). Thickened basement membrane (curved arrow) and luminal border microvilli (MV) are perceived. notice. Nucleus $(\mathrm{N})$ and lysosome (L). (electron microscopy, $\mathrm{x} 8000)$

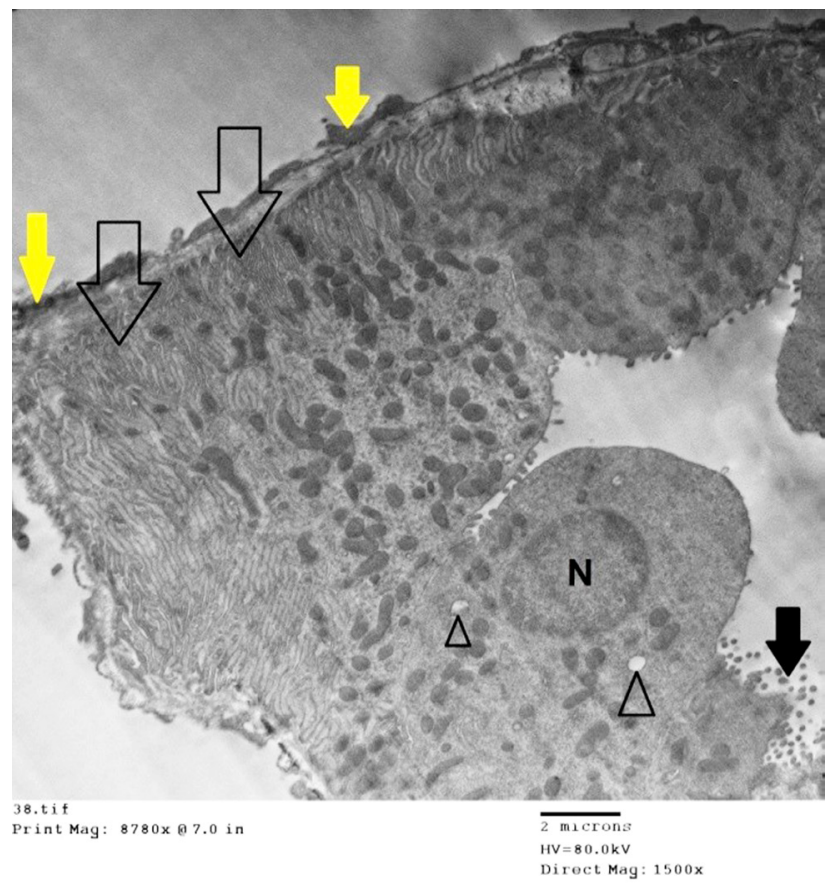

Fig. 17: Transmission electron micrograph of group III (low dose VD group) in distal convoluted tubule, showing apical scarce short microvilli (solid arrow), wide-ranging basal infoldings with few basal elongated mitochondria (hollow arrow) with plentiful scattered mitochondria. Cytoplasmic vacuoles (arrow head) and congealed basement membrane (yellow arrow) are seen. Notice the rounded nucleus $(\mathrm{N})$. (electron microscopy, $\mathrm{x} 8000$ )

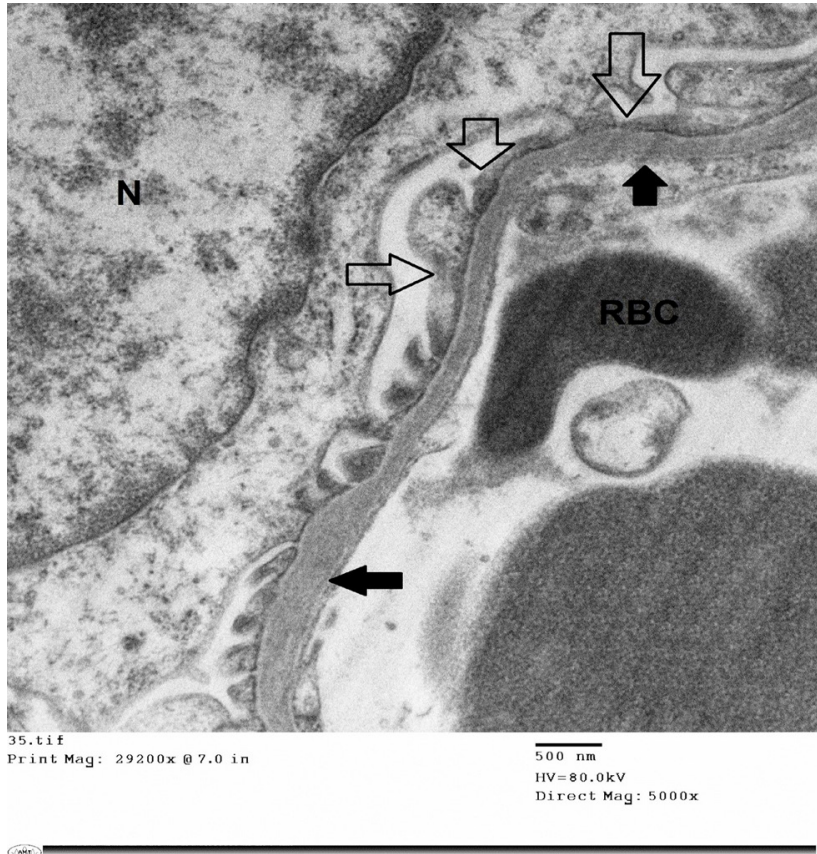

Fig. 18: Transmission electron micrograph from group III (low dose VD group), showing glomerular basement membrane, podocytes foot processes with area of effacement (hollow arrow). Restricted thickening of the basement membrane (black arrow). nucleus part of podocyte (N) can be appreciated. Red blood corpuscles (RBC) inside the glomerular capillary lumen are noticed. (electron microscopy, x 29200)

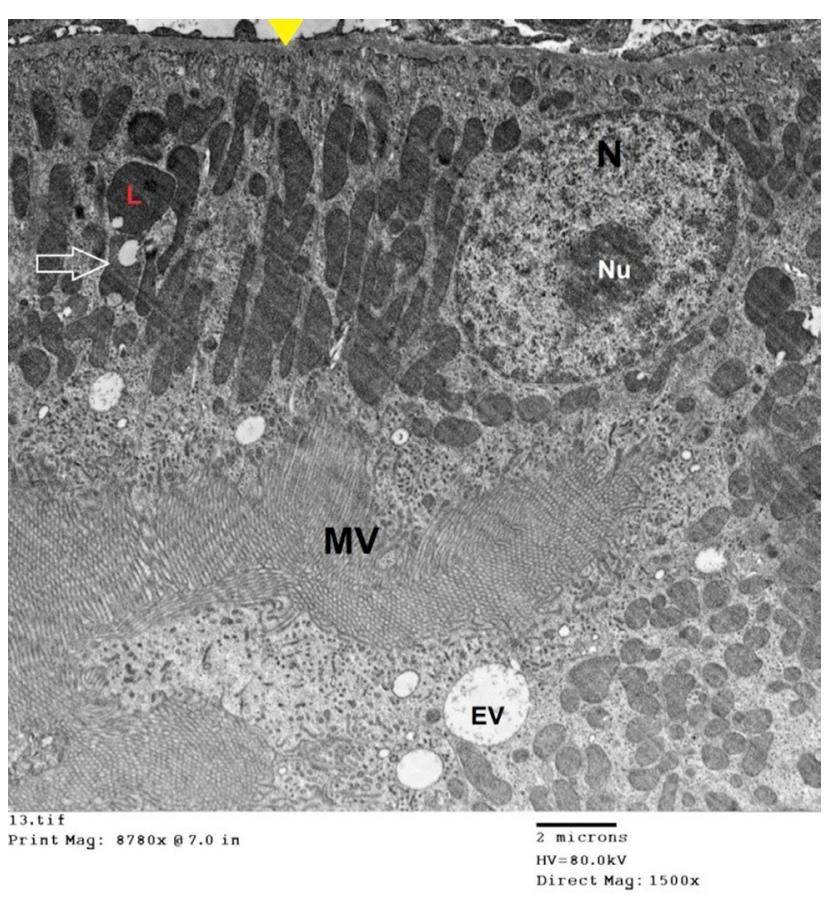

Fig. 19: Transmission electron micrograph of ultrathin sections of cortex of group IV (high dose VD group), showing part of PCT with virtually normal ultrastructure. notice less thickened uniform basement membrane (arrow head) basal elongated mitochondria (M) with basal infoldings. Notice; rounded euchromatic nucleus $(\mathrm{N})$, nucleolus $(\mathrm{Nu})$ and lysosome (L). Minor and major endocytotic vesicles (EV) in apical cytoplasm are evident and luminal border microvilli (MV) are noticeable. The hollow arrow denotes to vacuolated destructed mitochondria. (electron microscopy, $\mathrm{x} 8000$ ) 


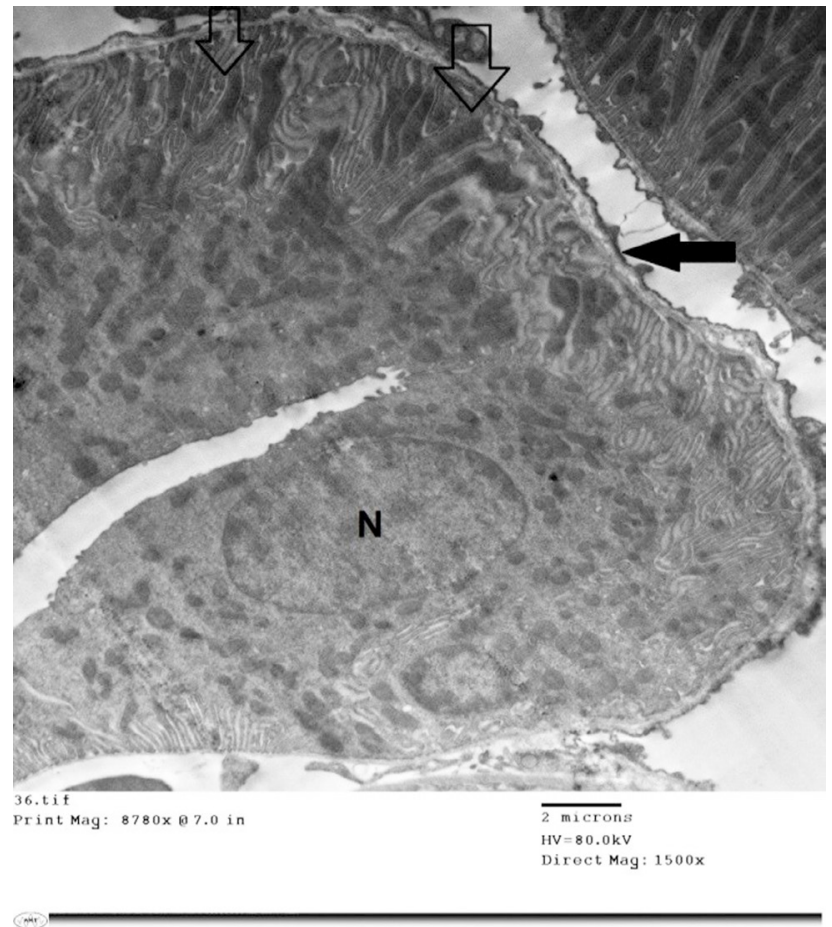

Fig. 20: Transmission electron micrograph of group IV (high dose VD group) in DCT, showing basal infoldings and their interrelated elongated mitochondria (hollow arrow), close on normal distribution of organoids, relatively slim basal lamina (solid arrow). Notice rounded nucleus $(\mathrm{N})$ with normal chromatin distribution. (electron microscopy, x 8000 )

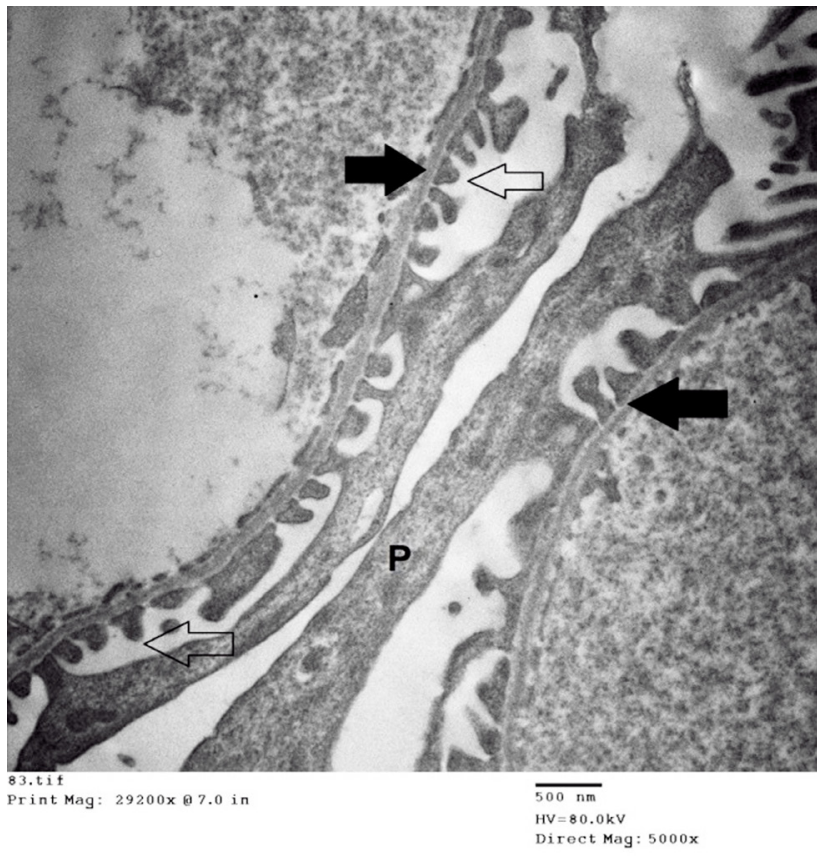

Fig. 21: Transmission electron micrograph from group IV (high doseVD group) of renal cortex, showing glomerular basement membrane and podocyte $(\mathrm{P})$. The shape of podocytes foot processes (hollow arrow) is emerge almost to control group. The glomerular basement membrane (black arrow) appear beyond uniform in diameter. (electron microscopy, x 29200)

Table 1: Showing measurements of serum fasting glucose level $(\mathrm{mg} / \mathrm{dl})$ in wholly groups

\begin{tabular}{lcccc}
\hline & Group I & Group II & Group III & Group IV \\
\hline Mean & 81.4 & 346.7 & 169.4 & 107.1 \\
SD & 0.80354 & 1.58695 & 0.79392 & 0.07642 \\
P value & & & 0.1198 & 0.01547 \\
Significance & & & $\mathrm{s}$ & $\mathrm{s}$ \\
\hline \multicolumn{3}{c}{$\mathrm{SD}=$ standard deviation } & $\mathrm{S}=$ Significant
\end{tabular}

Table 2: Showing measurements of serum urea $(\mathrm{mg} / \mathrm{dl})$ and creatinine $(\mathrm{mg} / \mathrm{dl})$ in wholly groups

\begin{tabular}{|c|c|c|c|c|c|c|c|c|}
\hline & \multicolumn{2}{|c|}{ Group I } & \multicolumn{2}{|c|}{ Group II } & \multicolumn{2}{|c|}{ Group III } & \multicolumn{2}{|c|}{ Group IV } \\
\hline & urea & creatinine & urea & creatinine & urea & creatinine & urea & creatinine \\
\hline Mean & 22.1 & 0.58 & 67.2 & 3.1 & 32 & 1.28 & 26.7 & 0.99 \\
\hline SD & 1.9877 & 0.1099 & 5.2153 & 0.2323 & 2.1453 & 0.1542 & 0.0025 & 0.0098 \\
\hline$P$ value & & & & & 0.1077 & 0.2011 & 0.0017 & 0.0078 \\
\hline Significance & & & & & $\mathrm{s}$ & $\mathrm{s}$ & $\mathrm{s}$ & $\mathrm{s}$ \\
\hline
\end{tabular}

$\mathrm{SD}=$ standard deviation $\quad \mathrm{S}=$ Significant

Table 3: Showing the mean zone ratio e of antifibronectin expression and SD in wholly groups

\begin{tabular}{lcccc}
\hline & Group I & Group II & Group III & Group IV \\
\hline Mean & 0.48 & 5.77 & 2.08 & 1.1 \\
SD & 0.1488 & 0.1476 & 0.1478 & 0.1487 \\
P value & & & 0.0036 & 0.0088 \\
Significance & & & $\mathrm{S}$ & $\mathrm{S}$ \\
\hline
\end{tabular}

$\mathrm{SD}=$ standard deviation $\quad \mathrm{S}=$ Significant 


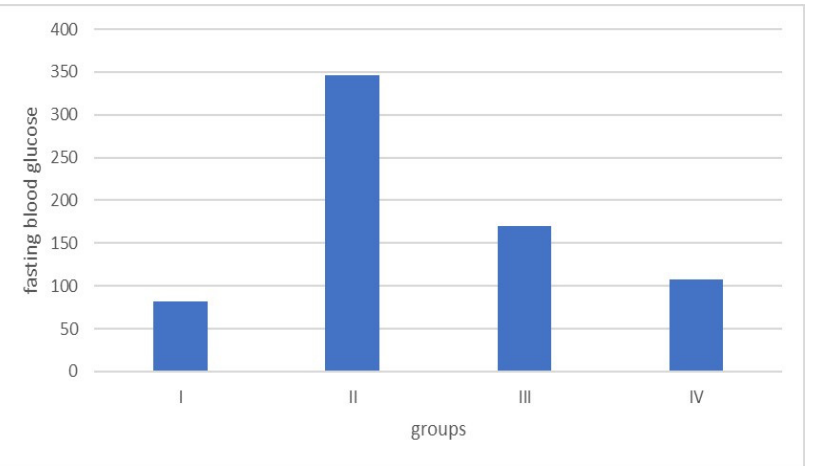

Histogram 1: The mean serum levels of fasting blood glucose (mg/dl) in wholly groups.

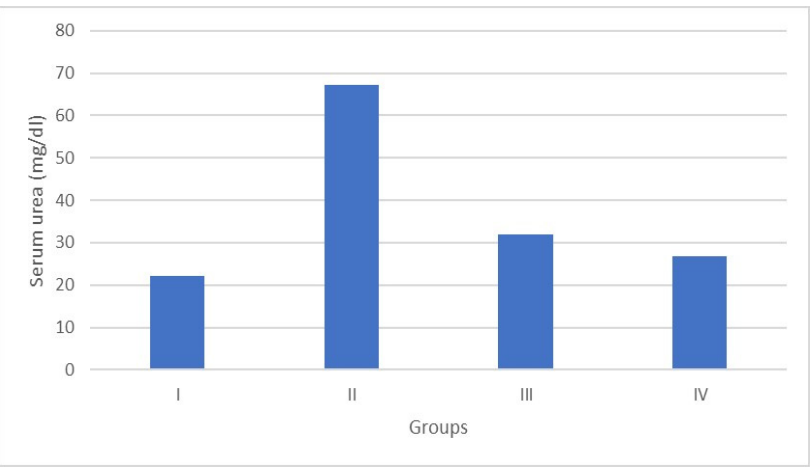

Histogram 2: The mean serum levels of urea $(\mathrm{mg} / \mathrm{dl})$ in wholly groups.

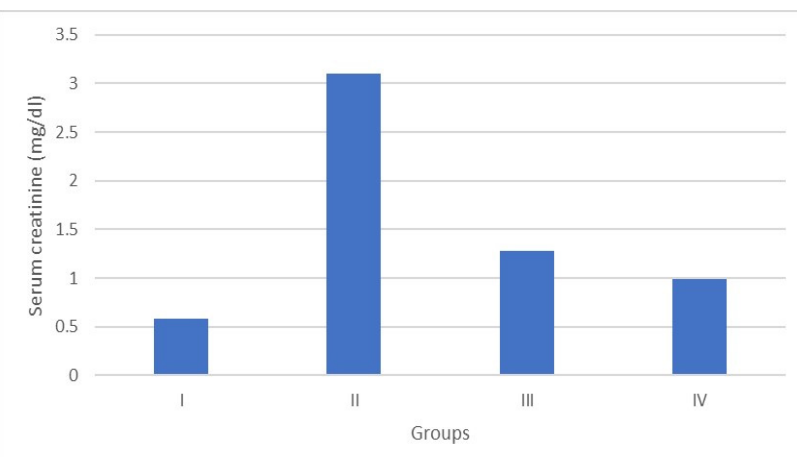

Histogram 3: The mean serum levels of creatinine $(\mathrm{mg} / \mathrm{dl})$ in wholly groups.

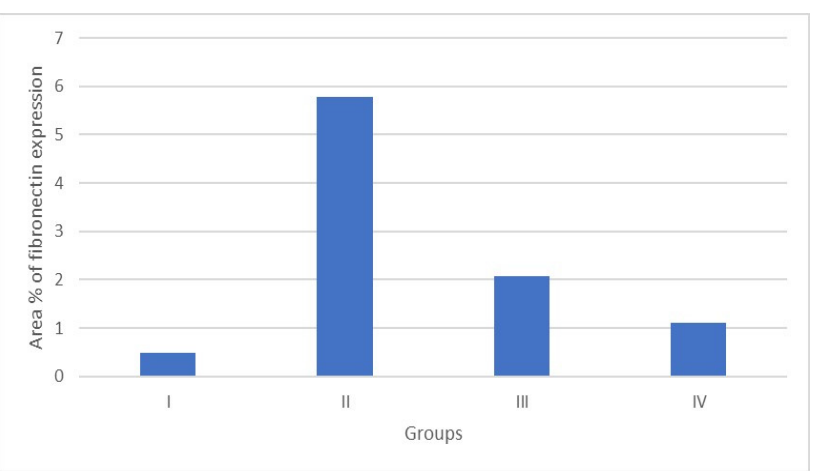

Histogram 4: The mean zone ratio $\%$ of fibronectin expression in all groups.

\section{DISCUSSION}

Diabetes is one of the communal syndromes whose prevalence is increasing vastly worldwide. Diabetic nephropathy (DN), is a severe microvascular impediment in cooperation of type I and type II diabetes mellitus and achieve trigger of renal failure. Diabetic nephropathy (DN) can hasten macrovascular complications and cardiovascular malady. Conventional existent therapies are not totally efficient in the medication of DN, alluding that auxiliary interpretation of the molecular basis of the pathogenesis of DN is compulsory for the value-added therapy of this disease $^{[23,24]}$

Vitamin D deficiency (VDD) has been acknowledged as a chief public healthcare problem. VDD prevalence among individuals with chronic kidney disease (CKD), has been reported to be as astronomical as $80 \%$. Over and above its crucial role in maintaining calcium and phosphorus homeostasis, VD has a modulating effect on essential biological processes for instance, redox balance, reninangiotensin-aldosterone system. vitamin $\mathrm{D}$ has a major part in endothelial palance and innate acquired immunity ${ }^{[5]}$

In the current analysis diabetes was invoked by intraperitoneal injection of streptozotocin liquefied in freshly prepared citrate buffer. To achieve the maximum permanency of streptozotocin solution avoiding its decomposition it must provide as five doses. Streptozotocin (STZ)-induced pancreatic grievance is commonly used as a rodent prototypical of diabetes mellitus type I. In the main, its boons had similar features to those institute in human diabetic nephropathy. STZ has discerning cytotoxicity for pancreatic $\beta$ cells. STZ enters $\beta$ cells by binding to glucose transporter (GLUT2). streptozotocin causes DNA alkylation, directing pancreatic $\beta$ cells to irreversible necrotic changes ${ }^{[25]}$.

With the intention of attenuating the nonspecific toxicity of STZ, manifold injections of low doses of STZ have been applied. Furthermore, this routine induces diabetes by triggering low-grade monotonous cell damage and lymphocytic infiltration ${ }^{[26]}$.

In the contemporary effort, Maintenance of the hyperglycemic status favored the elaboration of diabetic nephropathy. nephropathy evidenced by significant surge in serum fasting glucose, blood urea and serum creatinine matched to the control group. Significant histopathological changes. These finding were in resemblance with ${ }^{[27]}$.

Light microscopic assessment of Hand E stained kidney section of STZ rats revealed marked distortion of the structure of glomerulus with winding of Bowman's space. Peritubular arterial dilatation and hemorrhage associated with tubular distortion were also presented. This is in equivalence with $^{[12,30 \text {, and } 31]}$. Glomerular changes can be clarified by glomerular hyperfiltration, which pick up gradually after initiation of hyperglycemia. Hyperfiltration, which is one of the first events to be noticed in $\mathrm{DN}$, can trigger mechanical stretching which stimulates glomerular 
hypertrophy. ECM in excess of production in response to mesangial cell grievance ${ }^{[32]}$.

In accordance with ${ }^{[28]}$ Diabetic nephropathy retire from interaction between pathways of sophisticated glycosylation finale yields (AGEs) and oxidative stress. AGEs are the consequence of interaction of glucose along amino acid groups of proteins, nucleic acids and lipoproteins. AGEs amend basement membrane proteins, cross- yoke ECM elements, and surge expression of type IV collagen escorting to DN. AGEs interact with receptors on a variety of cell types such as macrophage cells, podocytes, and tubular cells. Receptor for AGE (RAGE) triggers intracellular and extracellular signaling conduits leading to immune reaction instigation. RAGE activation by AGEs leads to overproduction of reactive oxygen species (ROS) and instigation of transcription issues, for instance NF-kappa B. Transcription factors expand the release of transforming growth element -B1 (TGF-B1), interleukin-1B, interleukin-6 and tumor necrosis factor a (TNF-a).

These growth factors were the first action in the progression of diabetic impediments. ROS have a pivotal role in the oxidation of membrane lipids, DNA. Proteins, and carbohydrates were destructed in basement membrane. Deformations resulted from cell membrane disfigurement indicated impairment of functional and structural purpose of natural filtration. Hyperglycemia provokes deposition of almost all ECM proteins as fibronectin, laminin and collagens (type IV and type VI) ${ }^{[29]}$.

Dispensation of low dose vitamin D showed enhanced improvement of glomerular structure which delimited by Bowman's capsule, filtration space. The proximal convoluted tubules were utmost probably normal with preserved brush border. additionally, Dispensation of high dose vitamin D for induced visible ordinary structures of renal corpuscles and utmost of tubular lining epithelium of STZ rats. Collectively we proposition that high dose vitamin D improved renal histology in STZ induced DN in resemblance with $^{[33,34]}$.

Immunohistochemical staining revealed significantly increased heap of the protein fibronectin, an acknowledged indicator of nephropathy, in the kidneys of rats with diabetes (group II) in similarity with ${ }^{[32]}$ and to a slighter extent in group III. fibronectin hardly detected in group IV and control group. In 2018, de Braganca et al. submitted that Vitamin D deficiency provoked the immunostainings for both fibronectin and collagen IV markers and aggravated both renal inflammation and fibrosis. The conclusion that, vitamin $\mathrm{D}$ deficiency donated a prohibitive illustration of fibronectin and collagen $\mathrm{IV}^{[35]}$.

STZ treated (Group II) rats illustrated in electron microscopic results, cytoplasmic vacuolations and destructed mitochondria of proximal convoluted tubule. Also, DCTs of STZ treated rats illustrated disorganized short microvilli, disrupted lateral membrane with cytoplasmic vacuolations and comparatively thickened basement membranes. Renal corpuscle in STZ treated rats revealed roughly cytoplasmic vacuolations of podocyte and thickened glomerular basement membrane with effacement of podocyte foot processes in agreement with $^{[33]}$. In disparity, rats which gotten low dose vitamin D surfaced PCT with evidence of histological restructuring of the renal histology with regular microvilli. The DCTs had elongated mitochondria with nearly normal distribution of organoids. renal corpuscles expressed more regular thickness of glomerular BM and convalescence of podocyte foot processes. Farther, Rats which received high dose of vitamin D revealed apparently virtually normal tubule ultrastructure, well defined podocytes footed process with negligible effacement areas, uniform glomerular BM and evenly smoothly spaced fenestrae.

It is well known that inflammatory and immunologic means recreation a serious part in the evolvement and progression of $\mathrm{DN}^{[36]}$. Pro-inflammatory cytokines for instance IL-6 and TNF-a thickening are related with congealing of the glomerular basement membrane ${ }^{[37]}$. Calcitriol and Calcitriol3 a synthetic physiologicallyactive analog of vitamin $\mathrm{D}$ reduced mesangial proliferation and suppresses renin. Calcitriol3 negatively regulates renin angiotensin aldosterone coordination, through its suppression of TGF $-\beta$, macrophage permeation, and transcription factor nuclear factor- $\kappa b$ activity. Vitamin D has anti-inflammatory and antifibrotic activity ${ }^{[38]}$. In 2017 , Zeng X. et al. investigated consequence of vitamin D on a rat model of DM and created that calcitrioli and VD3 could diminish the expression of CD68, MCP-1 and TGF-B1 and attenuated macrophages infiltration in tissues. Vitamin D receptors (VDR) were expressed in the glomerulus, chiefly in podocytes and parietal epithelial cells. Reno protective role of vitamin D might thus be mediated locally by directly affecting the podocytefunction. In a recent study, explored the role of paricalcitol (a vitamin D analogue) in isolated rat glomeruli exposed to diabetic circumstances, concluded that Paricalcitol ameliorated podocyte grievance better in high dose than in low dose ${ }^{[39]}$.

\section{CONFLICTS OF INTEREST}

There are no Conflicts of Interest.

\section{REFERENCES}

1. Caramori ML, Kim Y, Huang C, Fish AJ, Rich SS, Russell G and Mauer M. Cellular origin of diabetic nephropathy: origin design, and renal structural, relationships, in tolerant $\mathrm{s}$ with long-standing type 1 diabetes. Diabetes 2002; 62: 606-613.

2. Hastings MC, Moldoveanu Z, Suzuki H, Julian BA, Sanders JT, Renfrow MB, Novak J, Wyatt RJ. Biochemicals, in $\mathrm{IgC}$ nephropathy: affiliation to pathogenetic hitse. Expert Opin Med Diagn 2013; 3: $311-330$ 
3. Sayid AA, Khaleefa M, Abd el-LatefFF. Fenugreek diminution of diabetic nephropathy, diminution of diabetic nephropathy in rats. J Physiol Biochem.; 2012.70: 222-233.

4. Cheoi SW, Benzie IF, Maa SW, Strainn JJ, Hanigan BM. Oxidative stress: direct reason and outcome? Free Radic Biol Med.; 2008.49:1119-1122.

5. Henrikue PF, Goiis MW, Ranganeathan DR and Antonio CS. Vitamin D Paucity, in Chronic Kidney Disease: Topical Evidence. Int J Environ Res Public Health; 2018. Aug; 15(8): 1773.

6. Pilz S, Trumer C, Panndis M, Schwuetz V, Abeerer F, Grübler M, Vereyen N, Tomaschitz A and März W. Vitamin D: Current Recommendations and Outlook. Anticancer Res.; 2018.38(2):1145-1151.

7. Hou H, Xee S, Hue S, Gao Y and Shui H. Influence of 1,25(OH)2D3 on trans: differentiation of tubular epithelial cells, induced by extraordinary glucose Biomedical Reports; 2016.5: 699-704.

8. Kikutae $\mathrm{J}$ and Ishi M: Current issues on Vitamin D. The properties of vitamin D and the immune system. Clin Calcium; 2015.25: 359-365.

9. Vurstuyf A, Carmaliet G and Mathieu C: Vitamin D: A pleiotropic analogues hormone. Kidney Int.; 2010.65: 133-144.

10. Afzsal $\mathrm{S}$ and Nordestggaard BG: Low vitamin D lead to hypertension: A connotation? Lancet Diabetes Endocrinol.; 2014.2: 682-684.

11. Nakashima A, Yokoyama $K$, Yokoo $T$ and Urashima M: Protagonist of vitamin D, in diabetes mellitus. World J Diabetes; 2016. 8: 77-88.

12. Yu R, Mao J, YangY, Zhangd Y, Tian Y and Zhu J. Protective possessions of calcitriol on diabetic nephropathy mediated, down regulation of TGF-B1 and CIP4 in diabetic nephropathy rats. Int. J. Clin. Exp. Pathol.; 2015. 3(7):3213-3221.

13. Shui IM, Mondoul AM, Linkström S, Travis RC, Gerke T, Albanes D, Giovannucci E and Kraft P; Breast and Prostate Cancer: Vitamin Dcorrelated genetic dissimilarity. Cancer; 2015.121: 1949-1956.

14. Baroen JA, Barry EL, Motgt LA, Sandler RS, Snovesr DC, Bostick RM, Ivanova A, Cole BF, Ahnjn DJ, et al: A probationary of calcium and vitamin $\mathrm{D}$, for the preclusion of colorectal adenomas. N Engl J Med; 2015. 333: 1429-1438.

15. Reiners LL, Crew KD, Brakshaw PT, Samtella RM, Steck SE, Sirosh I, Terry MB, Hershman DL, Shane E, Cremers S, et al: Vitamin D- allied gene p. olymor ph isms and breast cancer jeopardy. Cancer Causes Control; 2015. 17: 127-131.
16. Leyssens $\mathrm{C}$, Verlinden $\mathrm{L}$ and Verstuyf $\mathrm{A}$ : Antinoeplastic possessions of 1,25 $(\mathrm{OH}) 2 \mathrm{D} 3$ and its analogs in prostate and colorectal sarcoma. Endocr Relat Cancer; 2013. 10: R34-R40.

17. Furman BL. Streptozotocin-Induced Diabetic Models in Mice and Rats. Current protocols in pharmacology; 2015.70:5.47.1-5.47.20

18. Willimson L, Hayes A, Hanson ED, Pivonka P, Sims NA and Gooi JH. High dose dietary vitamin D3 increases bone mass and strength in mice. Science Direct; 2017.volume 6, p 44-50.

19. Bancroft JD, Layton C. The hematoxylin and eosin and Connective and mesenchymal tissues with their stains [chapters 10 and 11]. In:Suvarna SK, Layton C, Bancroft JD, editors. Philosophy and preparation of histological techniques. $7^{\text {th }}$ ed Philadelphia: Churchill Livingstone of Elsevier; 2013. pp. 179-240.

20. Jakkson P, Blqthe D. Immunohistochemical performances [chapter 8]. In:Suvarna SK, Layton $\mathrm{C}$, Bancroft JD, editors. Theory and run-through of histological techniques. $7^{\text {th }}$ ed. Philadelphia: Churchill Livingstone of Elsevier; 2013. pp. 267-376.

21. Parck CH, Tanaka T, Shibaharw N and Yokozava T. Glycerol- convinced damage, improved by 7-o-Galloryl-Desdohepwtulose cure concluded tempering 0xidative stress. Bi01. Pharm. ;2012. 53(1):22-31.

22. Hayaty MA. Chemical fixation [chapter 2]. In: Hayat MA, editors. Principles and techniques of biological applications. $4^{\text {th }}$ ed. UK: Cambridge University Press; 2000. pp. 7-99.

23. Erenj Z, Bakkir EA, Coban J, Çağlayan B, Eksimci N, Ethemoglu S, Albayrak O, Akdeniz T, Kiliç E and Kanktarci G. Effects of Paricalcitol and Aliskiren Combination Therapy. on Investigational Diabetic Nephropathy. Kidney Blood Press Res.; 2014. 29:562-571.

24. Kxeshri UPD, Kumdar M, Loc BPD, Sharmna $\mathrm{J}$ and Kumar R. Validity of co- presidency of voglibose and vildagliptin on diabetic albino rats. International J. Basic \& Clinical Pharma.; 2016. 4(6): 1722-1732.

25. dee laa Garza-Rodea AS, Kenän-Shanzer S, Verxaegen APL and vab Bekkhum DW. AnomerEquilibrated Streptozotocin, Clarification for the Diabetes. J. Am. Assoc. Lab. Anim. Sci.; 2010.59 (2): 44-50

26. Kifada M, Ogwqra Y and Kovya D. Rodent diabetic nephropathy, their helpfulness and limitations. Int J. Nephrol. Renovasc. Dis.; 2016.10: 262-276. 
27. Kubel AM, Aletaibi SN, Alswat NM, Aldajani MS and Alnofaie MS. Effect of the combination between, Metformin on testing -Induced Diabetic Nephropathy. Int. J. Pharm. Sci \& Scient. Res.; 2016. 3(2), 103-109.

28. Kinadn M, Yav H, Martinxzz SQ and Kar P. Notions in Diabetic Nephropathy: From Pathobiology to Dealing. J. Ren. Hepat. Disord.; 2017. 2(3):19-34.

29. Uil M, Scantleberx AML, Larsen PWB, de Boer OJ, Leemans JC, Florquin S and Roel0fs JJTH. Merging streptozotocin and nephrectomy, is an applicable method for persuading experimental diabetic nephropathy. Scientific reports; 2018.8:5542.

30. Fernanges SM, Cordeiro PM, da Fonseca CD, de Fatima $\mathrm{M}$ and Vattimo $\mathrm{F}$. The protagonist of oxidative stress, in streptozotocin-induced diabetic nephropathy in mice. Arch. Endocrinol. Metab.; 2016. 50(6):413-466.

31. Qieoo Y, Gao K, Wangy Y, Wangx X and Cuii B. Resveratrol, changes diabetic nephropathy in rats through deleterious parameter of the MAK/TG-B1 pathway. p38 Exp Ther Med.; 2017 Jun; 13(6): 3223-3230.

32. Blaine J. Proteinuria: Basic Mechanisms, Pathophysiology and Clinical Relevance, Springer; 2016.ch. 4 ;45-46.

33. Zeng X, Li F, Quan L, Yao H and Zhu J. Upshots of 1, 25-dihydroxyvitamin D3, on TGF-B1, CD68 and MCP-1 diabetic nephropathy. Biomedical Research; 2017. 28(11): 4797-4802.

34. Maity B, bora $M$ and Sur D. A validity of combination of resveratrol, with vitamin D3 on modulation of cytokines, in diabetic nephropathy. Oriental Pharma. and Exper. Medi.; 2018.18(2): 127-138.

35. de Bragansaa AC, Candlele D, Gonçaleves JG, Seguro AC and Volpini RA. Vitamin D Deficiency Pesters the Renal Features of Moderate Chronic Kidney Disease. Front Med (Lausanne); 2018.5: 282.

36. You H, Gao T, Raup-Konsavage W M, Cooper, TK, Sarah K, Bronson SK, Reeves W B and Awad AS. Podocyte-specific chemokine (C-C motif) receptor 2 overexpression, umpires diabetic renal injury in mice. Kidney Int.; 2017. 71(3): 611-662.

37. Wu Z, Xie Z, Liu J, Wu Q and Wang X. Renoprotective Effect of Berberine on Streptozotocin-induced. Diabetic Nephropathy Rats. International J.Pharma.;2017.14:248-259.

38. Prabhu RA and Saraf K K.Vitamin D in diabetic nephropathy. J. Postgrad. Med.; 2018 67(1): $15-26$.

39. Trohatou Q, Tsilibary E, Charonis A, Iatrou C and Drossopoulou G. Vitamin D3 ameliorates podocyte grievance, through the nephrin signalling conduit. J. Cell Mol. Med.; 2017.22(10): 2569-2599. 


\title{
الملخص العربى
}

\section{تأثير الجرعات المنخفضه والعاليه من فيتامين د3 على الاعتلال الكلوي السكرى

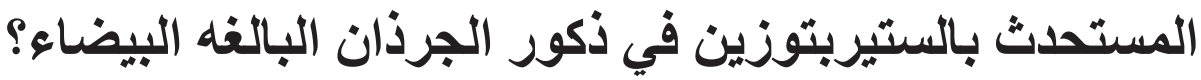 \\ دراسه هيستولوجيه وهيستوكيميائيه مناعيه}

\author{
رانيا إبراهيم، علا مصطفي وايناس محمد \\ قسم الأنسجة وبيولوجيا الخلية ــ كلية الطب - جامعة بنها
}

المقدمة: الاعتلال الكلوي السكري من اهم أسباب امر اض الكلي المزمنة والفشل الكلوي. نقص فيتامين د أصبح من مشاكل الصحة العالمية وحاليا يعتبر عملا رئيسيا في بداية وتقدم داء السكري. الهذف: يهدف هذا البحث الى تقييم التأثير المحتمل للجرعات المنخفضة والعالية لفيتامين د على الاعتلال الكلوي السكرى المستحث تجريبيا في الجرذان. مواد وطرق البحث: نم تقسيم اربعين من الجرذان الذكور البالغين الي أربع مجموعات. المجموعة الأولى: مجموعة ضابطه. المجموعة الثانية :(مجموعة الاعتلال الكلوي السكري (أعطيت الجرذان سترييتوزين عن طريق الحقن في التجويف البريتوني. المجموعة الثالثة:(مجمو عة فيتامين د الجرعة المنخفضة) أعطيت الجرذان ستريبتوزين عن طريق الحقن في التجويف البريتوني ثم أعطيت فيتامين د عن طريق الفم بجر عه 8000 وحده دوليه لكل كجم. المجموعة الر ابعة :( مجمو عة فيتامين د الجر عة العالية (أعطيت الجرذان ستريبتوزين عن طريق الحقن في التجويف البريتوني ثم أعطيت فيتامين د عن طريق الفم بجر عه 20,000 وحده دوليه لكل كجم. بعد انقضاء 12 أسبوع من بداية التجربة. تم تجهيز عينات من الكلي وفحصت باستخدام تقنيات هيستولوجيه وهستوكيميائية مناعيا. النتائج: أظهرت مجموعة الاعتلال الكلوي السكري تجويفات فى سيتوبلازم خلايا الأنيبيات ، وتفلطح فى الخلايا المبطنة للأنيبيات الكلوية ، وخروج السيتوبلازم و الأنوية إلى التجويف الداخلى للأنيبيات، ومواد هيلينية (قو الب زجاجية) فى تجويف الأنيبيات. و أما الفحص بالمجهر الإلكترونى للأنيبيات الملتوية القريبة والبعيدة فقد أظهر تجويفات متعددة، وأجسام هاضمة، وفقد لبعض أجزاء الجزء العلوي للجدار الخلوى، ووجود بقايا خلوية فى تجويف الأنيبيات، وميتوكوندريا ذات تجاويف، وأظهرت المجموعة الثالثة تحسن ضئيل لهذه التغيرات. و على الجانب الآخر أظهرت المجمو عة الر ابعة تحسن فى معظم هذه التغيرات. الخلاصة: فيتامين د بالجر عات العاليه أدي إلى تحسن من الاعتلال الكلوى السكرى. 